Volume: 12 Issue: 1 Year: 2015

\title{
Investigation of burnout in marriage
}

\author{
Mustafa Pamuk ${ }^{1}$ \\ Emine Durmuş ${ }^{2}$
}

\begin{abstract}
Aim of this study is to investigate of couple burnout in terms of some demografic variables, spousal support, dyadic trust, and interpersonel cognitive distortions in Turkey. The participant of the study is 482 married individuals, who are 271 female, 211 male live in Elazı̆g. To collect data; personel information form, Marriage Burnout Scale-Short Form (MBS-SF), Dyadic Trust Scale (DTS), Spouse Support Scale (SSS), and Interpersonel Cognitive Distortions Scale (ICDS) were applied to participants. To analyse data; correlation, $\mathrm{t}$ test, ANOVA and structural equation model (SEM) were used. Results revealed that there were significant differences between couple burnout and independent variables (gender, types of marriage, consanguineous marriage, number of children, and education level ). According to results from SEM, 44\% variance of couple burnout was explained by spousal support, dyadic trust, and interpersonel cognitive distortions. The results of the study were discussed together with the results of different studies and suggestions were made.
\end{abstract}

Keywords: Couple Burnout, Spousal Support, Dyadic Trust, Interpersonel Cognitive Distortions, and Marriage.

\section{Introduction}

Today, one of the most important problems faced among people is burnout. Burnout was first defined by Freudenberger (1974) as "a negative, job related psychological state comprising a set of symptoms such as physical fatigue, emotional exhaustion, and loss of motivation." The most widely used definition of burnout has been stated by Maslach. Maslach defined burnout as “"، a common emotional fatigue (burnout) and a cynicism syndrome among the individuals who work face-to-face with people and do jobs that involve human process as compared to mechanic or technical process" (Maslach and Jackson, 1981: 99). There are a number of studies on burnout in the literature. According to such research, burnout has been found to be related to numerous

\footnotetext{
1 Res. Asst., Frrat University, Faculty of Education, Educational Science Department, Guidance and Counseling Program, mustafapamuk@,firat.edu.tr

2 Assist. Prof. Dr., İnönü University, Faculty of Education, Educational Science Department, Guidance and Counseling Program, emine.durmus@inonu.edu.tr
} 
Pamuk, M., \& Durmuş, E. (2015).Investigation of burnout in marriage. International Journal of Human Sciences, 12(1), 162177. doi: $10.14687 /$ ijhs.v12i1.3002

negative variables such as depression (Gito, Ihara and Ogata, 2013; Glass, McKnight, and Valdimarsdottir,1993), stress (Kim and Lee, 2013; Yalçın, 2013), low level of life satisfaction (Kozak, Kersten, Schillmöller and Nienhaus, 2013), and low level of happiness (Schaufeli, Bakker, Van der Heijden, and Prins, 2009). Physical and emotional problems such as fatigue, lack of sleep, loss of appetite, headaches, digestion problems, exhaustion and depression, anxiety, desperation, loss of self-respect, sensitivity, frequent crying are often encountered in people with burnout syndrome (Torun, 1995). Burnout emerges as a problem threatening professional life to an important extent in terms of both the individual and organizations (Sağlam-Arı and Çına-Bal, 2008). Recently, burnout has not only been analyzed with regard to the personnel of occupational groups but has also come into attention in every field where people are. One of these fields is burnout in married individuals (Leaman, 1983; Pines, 1996). According to Çapri and Gökçakan (2013), Psychoanalytic-Existentialist Partner Burnout Model of Pines comes to the fore as the theoretical foundation of the studies conducted in the field of couple burnout. According to Pines (2005), both unconscious love and career choices reflect the individual's personal and familial history. We choose a career and a romantic partner that enable us to replicate significant childhood experiences and gratify ungratified childhood needs. People who expect to derive a sense of existential significance from their love relationships enter their love relationships with high hopes, committed and motivated. When they feel that they have failed, that intimate relationship is insignificant, that they make no difference, they start feeling helpless and hopeless and eventually burn out. According to Pines (1996), couple burnout is caused by a combination of unrealistic expectations and vicissitudes of life. It is not caused-as most clinical approaches to couple therapy believe-by a pathology in one mate, in both mates, or in the relationship.

\subsection{Spousal support and burnout}

One of the fundamental relationships between men and women is marriage. Individuals get married for numerous different reasons: to be happy, have children, establish an intimate relationship, satisfy sexual desires, and meet the expectations of the society. According to Çağ and Ylldirım (2013), a satisfactory marriage provides emotional, social and physical intimacy for partners. Close emotional support provided by the partner expresses the partner that he/she is valued, loved, respected, and valuable as a person. In their study on the physical benefits of marriage, Kiecolt-Glaser, and Newton (2001) states that good marriages help couples cope with depression. According to this, the resistance of partners to struggle with states of stress and depression may become weaker in married individuals as the social support of the partners for each other declines. This may cause marriage burnout. Social support is defined as a resource that 
Pamuk, M., \& Durmuş, E. (2015).Investigation of burnout in marriage. International Journal of Human Sciences, 12(1), 162177. doi: $10.14687 /$ ijhs.v12i1.3002

reduces or eliminates negative effects of stress. Individuals with a high level of social support are in better physical and mental health (Anis-ul-Haque and Sohail, 1997). In the study carried out on primary education teachers, Gündüz (2005) has found that the teachers who do not get social support express higher levels of burnout compared to the ones who get social support. Greenglass and Burke (1988) found that social support is one of the significant predictors of burnout. In this context, spousal support can be considered as one of the most important predictor of burnout in marriages as well.

\subsection{Cognitive distortions and burnout}

Cognition is one of the important subjects in which the relationship of the partners with their satisfaction is examined. Cognition in marriage is a structure that embodies different cognitive components such as attributions to the marriage and the other partner, dysfunctional thoughts, and problem solving processes in marriage (Güven and Sevim, 2007). One of the numerous factors that affect marriage burnout is irrational expectations towards the marriage and partner. Partner burnout depends on the harmony of a partner with the other partner's faith. From Beck's point of view, when couples lose their passion and love, even one disappointing event is enough for them to put negative labels on their spouses. In this case, lack of understanding from the husbands makes him unemotional in his wife's mind; and if the wife does not grant the husband's expectations, then the husband thinks the wife is being unkind. (Koolaee, Adibrad and Sedgh, 2009). Unrealistic expectations towards the marriage and partner may bring about disappointments and unhappiness (Güven and Sevim, 2007). When the related literature is examined, it is seen that irrational belief affects burnout (Ohue, Moriyama and Nakaya, 2011). Epstein and Eidelson (1981) found a relation between unrealistic standards among partners and marriage problems.

\subsection{Dyadic trust and burnout}

Trust is among the leading factors that affect human relations. Trust is also an important factor regarding marriage besides being one of the crucial factors that ensure togetherness among the individuals comprising the family, which forms the basic structure of the society. Dyadic trust can be defined as the amount of benevolence and honesty a partner feels their significant other expresses toward them (Larzelere \& Huston,1980). Beckenbach, Patrick and Sells (2010) state that relational trust (Couch and Jones, 1997) is focused on the quality or the confidence that a specific relationship is likely to be positive, sustaining, or enhancing to the self. It is in the bilateral exhibition of trusting and trustworthiness that there is no need to utilize defensive protections. 
Pamuk, M., \& Durmuş, E. (2015).Investigation of burnout in marriage. International Journal of Human Sciences, 12(1), 162177. doi: $10.14687 /$ ijhs.v12i1.3002

However, in the absence of both, or the unequal distribution of either by both partners, the need for defensive protection becomes necessary. Butler (1986) found that partner's desire to control others had a negative effect on trust, and self-esteem had a positive effect on trust. In their study conducted with 188 married individuals, Vinkers, Finkenauer and Hawk (2011) examined the relation between intrusive behavior (checking partner's text messages without his/her permission), trust, and perceived partner disclosure. According to the results of this study, perceiving a lack of partner disclosure is linked to intrusive behavior, and importantly, that trust moderates this link. Only when people did not trust their partner were their perceptions of partners' low disclosure associated with intrusive behavior. When people trusted their partner, perceived partner disclosure was not associated with intrusive behavior. In consideration of the literature, while some situations seen as problem can easily be overcome as the trust between partners increase, the same situation can not be overcome easily when the trust decreases. Moreover, another salient point in the literature is the fact that the desire of one of the partners to control the other causes a negative impact on the partner desired to be controlled.

\subsection{Purpose of the Study}

Today, as family violence and divorces have rapidly been increasing, the examination of the relationship between partners and the dynamics regarding marriage has become more important. In this context, the purpose of this study is to investigate burnout in married individuals that has numerous negative effects on individuals. In parallel with this purpose, answers for the following questions are sought:

1. Does the variable of burnout in marriage differentiate according to several demographic variables regarding married individuals?

2. Do the variables of spousal support, dyadic trust, and cognitive distortions in couple relationships predict the variable of marriage burnout?

\section{Method}

\subsection{Participants}

482 married individuals living in Elazı $\breve{g}$, of which 211 (43,7\%) are male and 271 (56,3\%) are women, participated in the study. $265(54,9 \%)$ of the participants stated that they had an arranged marriage whereas $217(45,1 \%)$ married by acquaintance. $143(29,6 \%)$ of the participants stated that their partners are consanguineous, whereas 339 (70,4\%) stated they are not. When the state of having children is examined, it has been found that $55(11,4 \%)$ of the participants do not have any 
Pamuk, M., \& Durmuş, E. (2015).Investigation of burnout in marriage. International Journal of Human Sciences, 12(1), 162177. doi: $10.14687 /$ ijhs.v12i1.3002

children, 98 (20,3\%) have one child, 275 (57\%) have 2-4 children, and $54(11,3 \%)$ have 5 or more children. When it is examined based on the variable of the level of education, it has been found that $35(7,2 \%)$ of the participants are illiterate, $102(21,1 \%)$ are primary school, $78(16,1 \%)$ are secondary school, 115 (23,8\%) are high school, and $152(31,8 \%)$ are university graduates. Besides, the average age of the participants has been determined as $37,6(\mathrm{Ss}=9,8)$ and the average period of marriage as $14,3(\mathrm{Ss}=10,5)$.

\subsection{Tools of Data Collection}

Personal Information Form: In this form, there were questions to determine the gender, number of children, level of education, type of marriage, and whether the partners were consanguineous or not.

Marriage Burnout Scale-Short Form (MBS-SF): Instead of Pines' (1996) Partner Burnout Scale (PBS) comprised of 21 items, Pines et al (2011) used a shorter form of this scale that has 10 items and has been used in order to create a measuring tool that is easier to use and comprises of less items to meet the need of researchers. The shorter form with 10 items was adapted to Turkish by Çapri (2013). In the analysis of the scale regarding language validity, correlation was found as .94. In the Exploratory Factor Analysis of the scale, item factor loads were found to vary between .49 and 83. While the Cronbach alpha coefficient of PBD-SF was calculated as 0.91 , item-total test correlations were found to vary between 0.41 and 0.76 and it has been observed that test-retest coefficient of correlation was $\mathrm{r}=0.90(\mathrm{p}<0.01)$.

Dyadic Trust Scale (DTS) : DTS was developed by Larzelere and Huston (1980); was adapted to Turkish by Çetinkaya, Kemer, Bulgan and Tezer (2008). Item-total correlations of the scale vary between .55 and .88; factor loads vary between .46 and .91. Cronbach alpha coefficient DTS is .89. Moreover, in convergent validity, significant relationships were found between DTS and Marriage Life $(r=.65, \mathrm{p}<.01)$, and DTS and Emotional Attachment Scale $(r=.60, \mathrm{p}<.01)$.

Spouse Support Scale (SSS): SSS was developed by Yildırım (2004) in Turkish culture. Validity of SSS was tested by factor analysis and convergent validity. As a result of factor analysis, it was determined that SSS had four factors (emotional support, instrumental and information support, appraisal support, and social companionship). In addition, negative significant relationship between SSS and Beck Depression Inventory (BDI)-Turkish Form was detected $(r=-.276)$. Reliability study of SSS was calculated in two ways: Cronbach Alpha coefficient of SSS was found to be .95, whereas test-retest reliability coefficient as .89 .

Interpersonel Cognitive Distortions Scale (ICDS): The scale was developed in order to assess cognitive distortions displayed by individuals in interpersonal relationships (Hamamc1 and 
Pamuk, M., \& Durmuş, E. (2015).Investigation of burnout in marriage. International Journal of Human Sciences, 12(1), 162177. doi: $10.14687 /$ ijhs.v12i1.3002

Büyüköztürk, 2003). In the scale, there are 19 items including cognitive distortions in relationships. High point indicates that individuals have cognitive distortions regarding relationships. The scale contains three factors independent from each other, namely "avoiding intimacy", "unrealistic relationship expentancy", and "mind reading". As a result of the item analysis performed on the scale items, it was observed that each item's adjusted item total correlation with its own subdimension varies between .49 and .20 , whereas other dual correlations with other dimensions vary between -.05 and .20. Dual correlations between the sub-dimensions of the scale were found to be between .07 and .15. This finding indicated that the relationships between the sub-dimensions of the scale were very low (Hamamcı and Büyüköztürk, 2003). Cronbach Alpha Coefficient of for the entire scale was found as .67. When examined for each sub-dimension one by one, it was calculated as .73 for the first sub-dimension; .66 for the second sub-dimension; and .49 for the third dimension. Test-retest coefficient was calculated for the entire scale is $.74 ; .70$ for the first subdimension; .76 for the second sub-dimension, and .74 for the third sub-dimension.

\subsection{Procedure}

For the purpose of data collection, personal information form, MBS-SF, DTS, SSS, and ICDS were applied to the participants. Scales were applied to illiterate participants by the implementer through reading and filled out. Frequency, percentage, average, standard deviation, correlation, $t$ test, one-way analysis of variance (ANOVA), and structural equation model were used in data analysis. Before starting analysis, coefficients of kurtosis and skewness were examined. Coefficients of kurtosis and skewness between +2 and -2 emphasize that the points display a normal distribution (Pallant, 2001). According to this, as seen in Table 1, for MB (1.4-1.2), DTS (.106--.1,04), ICDS (.148-.328), and SSS (.401-.789) kurtosis and skewness were found between -2 and +2 respectively. In addition, in order to be able to determine extreme values before the analyses, Mahalanobis distances were examined and 12 data were removed from the data set. In the final analysis, the number of participants were determined as 482 .

\section{Findings}

In this section of the research, results regarding the coefficients of correlation between variables, Cronbach alpha values, $\mathrm{t}$ test, ANOVA, and structural equation model were presented. Coefficients of correlation between variables, Cronbach Alpha values, coefficients of kurtosis and skewness are given in Table 1. 
Pamuk, M., \& Durmuş, E. (2015).Investigation of burnout in marriage. International Journal of Human Sciences, 12(1), 162177. doi: $10.14687 /$ ijhs.v12i1.3002

Table 1. Coefficients of correlation, Cronbach Alpha values and values of Kurtosis and Skewness

\begin{tabular}{|c|c|c|c|c|c|c|c|c|}
\hline & Variables & 1 & 2 & 3 & 4 & Cronbach Alpha & Kurtosis & Skewness \\
\hline 1 & MB & 1 & & & & .87 & 1,4 & 1,2 \\
\hline 2 & DT & $-.45^{* *}$ & 1 & & & .87 & .106 & $-1,04$ \\
\hline 3 & ICD & $.19 * *$ & $-.13 * *$ & 1 & & .79 & .148 & .328 \\
\hline 4 & SS & $-.57 * *$ & $.56^{* *}$ & $-.11 *$ & 1 & .92 & .401 & .789 \\
\hline
\end{tabular}

As seen in Table 1, a negative medium level relation between MB and DT $(r=-.45 ; \mathrm{p}<.01)$; a positive low relation between $\mathrm{MB}$ and $\operatorname{ICD}(\mathrm{r}=.19 ; \mathrm{p}<.01)$; a negative medium level relation between MB and SS ( $\mathrm{r}=-.57$; $\mathrm{p}<.01)$ were found. Besides, a negative low level relation between DT and ICD $(r=-.13 ; \mathrm{p}<.01)$; and a negative low level relation between ICD and SS ( $r=-.11 ; \mathrm{p}<.05)$ were found.

Tablo 2. Means, standart deviations and t values of MB according to gender

\begin{tabular}{|c|c|c|c|c|c|c|c|}
\hline \multirow[b]{4}{*}{ MB } & \multicolumn{4}{|c|}{ Gender } & \multirow{3}{*}{$\mathrm{t}$} & \multirow{3}{*}{$\mathrm{df}$} & \multirow{3}{*}{$\mathrm{p}$} \\
\hline & \multicolumn{2}{|c|}{$\begin{array}{c}\text { Male } \\
\mathrm{n}=211\end{array}$} & \multicolumn{2}{|c|}{$\begin{array}{l}\text { Female } \\
n=271\end{array}$} & & & \\
\hline & $\bar{X}$ & $\mathrm{Sd}$ & $\bar{X}$ & $\mathrm{Sd}$ & & & \\
\hline & 20 & 8,9 & 24,2 & 11,5 & $-4,386$ & 480 & $.000^{*}$ \\
\hline
\end{tabular}

In Table 2, the examination of marriage burnout according to the variable of gender is given. As seen in Table-2, there was a significant difference between males and females in relation to $\mathrm{MB}(\mathrm{t}(480)=-4,386 ; \mathrm{p}<.05)$. When these results analysed, it was seen that MB of females $(\bar{X}=$ $24,2 ; \mathrm{Sd}=11,5)$ was higher than the males $(\bar{X}=20 ; \mathrm{Sd}=8,9)$.

Tablo 3. Means, standart deviations and t values of MB according to marriage type

\begin{tabular}{|c|c|c|c|c|c|c|c|}
\hline \multirow[b]{3}{*}{ MB } & \multicolumn{4}{|c|}{ Marriage type } & \multirow{3}{*}{$\mathrm{t}$} & \multirow{3}{*}{$\mathrm{df}$} & \multirow{3}{*}{$\mathrm{p}$} \\
\hline & $\begin{array}{l}\text { Arra } \\
\mathrm{n}=\end{array}$ & $\begin{array}{l}\text { ged } \\
265\end{array}$ & $\begin{array}{l}\text { Acqu } \\
\mathrm{n}=\end{array}$ & & & & \\
\hline & $\begin{array}{c}\bar{X} \\
23,7\end{array}$ & $\begin{array}{r}\mathrm{Sd} \\
11,7\end{array}$ & $\begin{array}{c}X \\
20,6\end{array}$ & $\begin{array}{r}\mathrm{Sd} \\
8,9\end{array}$ & & & \\
\hline
\end{tabular}

In Table 3, the examination of marriage burnout according to the variable of marriage type is given. As seen in Table-3, there was a significant difference between arranged and acquainted marriages in relation to $\mathrm{MB}(\mathrm{t}(480)=3,132 ; \mathrm{p}<.05)$. When these results analysed, it was seen that MB of individuals who had an arranged marriage $(\bar{X}=23,7 ; \mathrm{Sd}=11,7)$ was higher than acquainted married individuals $(\bar{X}=20,6 ; \mathrm{Sd}=8,9)$. 
Pamuk, M., \& Durmuş, E. (2015).Investigation of burnout in marriage. International Journal of Human Sciences, 12(1), 162177. doi: $10.14687 /$ ijhs.v12i1.3002

Tablo 4. Means, standart deviations and t values of MB according to state of being consanguineous

\begin{tabular}{|c|c|c|c|c|c|c|c|}
\hline \multirow[b]{4}{*}{ MB } & \multicolumn{4}{|c|}{ State of being consanguineous } & \multirow{3}{*}{$\mathrm{t}$} & \multirow{3}{*}{ df } & \multirow{3}{*}{$\mathrm{p}$} \\
\hline & \multicolumn{2}{|c|}{$\begin{array}{c}\text { Yes } \\
n=143\end{array}$} & \multicolumn{2}{|c|}{$\begin{array}{c}\text { No } \\
n=339\end{array}$} & & & \\
\hline & $\bar{X}$ & $\mathrm{Sd}$ & $\bar{X}$ & $\mathrm{Sd}$ & & & \\
\hline & 24,1 & 11,7 & 21,7 & 10,1 & 2,233 & 480 & $.026^{*}$ \\
\hline
\end{tabular}

In Table 4, the examination of marriage burnout according to the variable of state of being consanguineous is given. As seen in Table-4, there was a significant difference between consanguineous and nonconsanguineous in relation to $\mathrm{MB}(\mathrm{t}(480)=2,233 ; \mathrm{p}<.05)$. When these results analysed, it was seen that $\mathrm{MB}$ of individuals who were consanguineous $(\bar{X}=24,1 ; \mathrm{Sd}=11,7)$ was higher than individuals who were nonconsanguineous $(\bar{X}=21,7 ; \mathrm{Sd}=10,1)$.

Table 5. Results of ANOVA of MB according to the variable of the number of children

\begin{tabular}{|c|c|c|c|c|c|c|c|c|c|c|c|}
\hline \multirow[b]{4}{*}{ MB } & \multicolumn{8}{|c|}{ Number of children } & \multirow{3}{*}{$\mathrm{F}$} & \multirow{3}{*}{$\mathrm{p}$} & \multirow{3}{*}{ Scheffe test } \\
\hline & \multicolumn{2}{|c|}{$\begin{array}{c}0^{\mathrm{A}} \\
\mathrm{n}=55\end{array}$} & \multicolumn{2}{|c|}{$\begin{array}{c}1^{\mathrm{B}} \\
\mathrm{n}=98\end{array}$} & \multicolumn{2}{|c|}{$\begin{array}{c}2-4^{C} \\
n=275\end{array}$} & \multicolumn{2}{|c|}{$\begin{array}{c}5 \text { and more }{ }^{\mathrm{D}} \\
\mathrm{n}=54\end{array}$} & & & \\
\hline & $\bar{X}$ & $\mathrm{Sd}$ & $\bar{X}$ & $\mathrm{Sd}$ & $\bar{X}$ & $\mathrm{Sd}$ & $\bar{X}$ & $\mathrm{Sd}$ & & & \\
\hline & 19,2 & 8,6 & 21,5 & 10 & 22,5 & 10,9 & 25,7 & 11,6 & 3,665 & $.012^{*}$ & $\mathrm{D}>\mathrm{A}$ \\
\hline
\end{tabular}

In Table 5, the results regarding the examination of $\mathrm{MB}$ according to the variable of the number of children are given. As seen in Table-5, a significant difference was found when marriage burnout is examined according to the variable of the number of children (No children, one child, 24 children, 5 and more children $)(F(3-478)=3,665 ; \mathrm{p}<.05)$. According to the Scheffe test performed in order to examine this significant difference, mean of married individuals with 5 or more children regarding $\mathrm{MB}(\bar{X}=25,7 ; \mathrm{Sd}=11,6)$ was found to be higher than that of those with no children $(\bar{X}$ $=19,2 ; \mathrm{Sd}=8,6)$.

Table 6. Results of ANOVA of MB according to the variable of the level of education

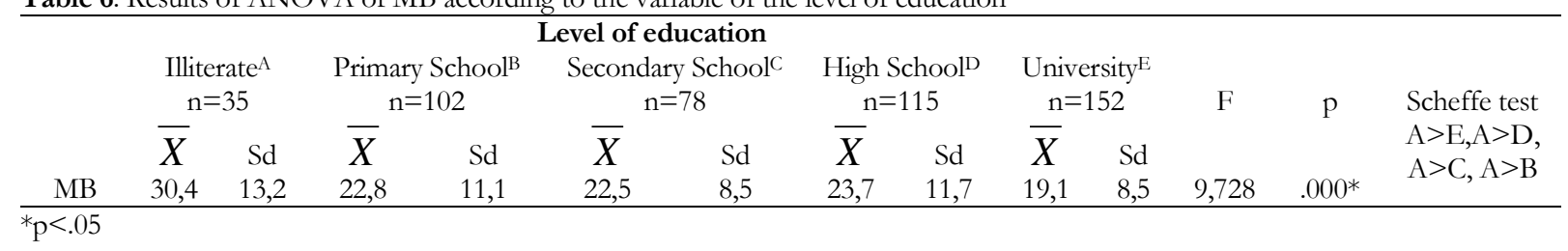

In Table 6, results regarding the examination of $\mathrm{MB}$ according to the variable of the level of education are given. As seen in Table-6, a significant difference was found when marriage burnout is examined according to the variable of the level of education $(F(4-477)=9,728 ; p<.05)$. According to the Scheffe test performed in order to examine this significant difference, mean of illiterate married individuals regarding $\mathrm{MB}\left(\bar{X}_{\mathrm{A}}=30,5 ; \mathrm{Sd}=13,2\right)$ was found to be higher than that of all 
Pamuk, M., \& Durmuş, E. (2015).Investigation of burnout in marriage. International Journal of Human Sciences, 12(1), 162177. doi: $10.14687 /$ ijhs.v12i1.3002

other married individuals at any level of education $\left(\bar{X}_{\mathrm{B}}=22,8 ; \mathrm{Sd}=11,1 ; \bar{X}_{\mathrm{C}}=22,5 ; \mathrm{Sd}=8,5 ; \bar{X}\right.$ $\left.{ }_{\mathrm{D}}=23,7 ; \mathrm{Sd}=11,7 ; \bar{X}_{\mathrm{E}}=19,1 ; \mathrm{Sd}=8,5\right)$.

In Figure 1, results of the analysis regarding the structural equation model on the variables that predict marriage burnout have been given.

The model was modified due to the fact that model fit indexes were not at the desired level at the beginning. According to this, a covariance was drawn between the error variances of the items t5-t6, t4-t5 in MB and g1-g2 in the DT. Chi square difference tests following each modification were observed and each modification was seen to make a significant contribution to the model. $\chi^{2} / \mathrm{df}$ ratio calculated when the model fit index is observed following the modification was 2,770 and this value indicated that the suggested factor model was in accordance with the data (Schumacker and Lomax, 2004; Sümer, 2000). GFI (.93), AGFI (.91), CFI (.95), TLI (.93), RMSEA (.06), and SRMR(.08) indicated that the fit values of the model was appropriate (Hooper, Coughlan, \& Mullen, 2008; Hu and Bentler, 1999; MacCallum, Browne and Sugawara, 1996; Schumacker and Lomax, 2004; Sümer, 2000; Y1lmaz and Çelik, 2009).

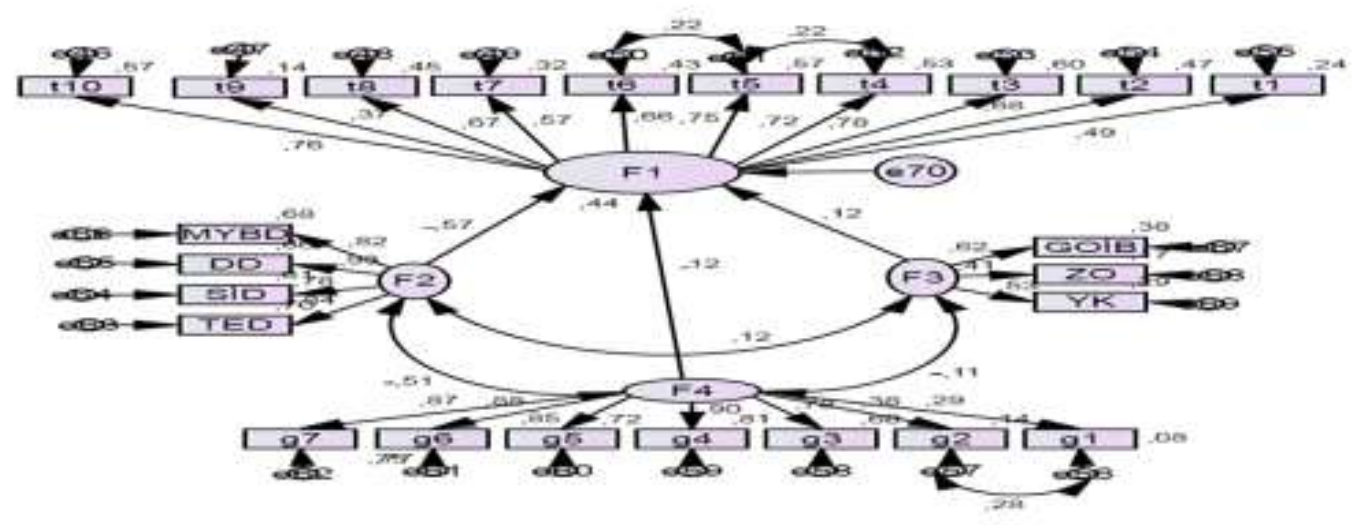

Figure 1. Structural equation model on the variables that predict MB

F1=MB; F2=SS; F3= ICD; F4= DT

$p=.000 ; C M I N=673,173 ; D F=243 ; C M I N / D F=2,770 ; G F I=.93 ; A G F I=.91 ; C F I=.95 ; T L I=.93 ; R M S E A=.06 S R M R=.08$

As seen in Figure 1, all parameters were found to be statistically significant in the estimation results of the model. Factor loads for the latent variable of F2 (SS) vary between .78 and .93; between .41 and .62 for the latent variable of F3 (ICD); between .29 and .90 for the latent variable of F4 (DT); and between .37 and .38 for the latent variable of F1 (MB). 44\% of the variance stated for the latent variable of $\mathrm{MB}$ was simultaneously explained with the direct impact of the variables of 
Pamuk, M., \& Durmuş, E. (2015).Investigation of burnout in marriage. International Journal of Human Sciences, 12(1), $162-$ 177. doi: $10.14687 /$ ijhs.v12i1.3002

SS, ICD, and DT. When standardized regression (Beta) coefficients were examined, it was found that SS had a negative impact on MB $(\beta=-.57 ; \mathrm{p}<.05)$, DT had a negative impact on MB $(\beta=-.12$; $\mathrm{p}<.05)$, and ICD had a positive impact on $\mathrm{MB}(\beta=.12 ; \mathrm{p}<.05)$.

\section{Results, Discussion and Suggestions}

In this study, burnout of married individuals were examined according to several variables (gender, type of marriage, state of being consanguineous, number of children, and level of education); then it was examined whether marriage burnout was predicted by some variables (SS, DT, and ICD) or not.

According to the results obtained from the research, it was found out that among married individuals, female experienced burnout at a higher significant level compared to male. When the studies on burnout in married individuals were examined, they indicated similar results to the ones obtained from this research (Çapri, 2013; Etzion and Pines, 1986; Pines et al., 2011; Ronen and Pines, 2008). In some studies, it is observed that results indicating that men, at the sub-dimension of depersonalization of Maslach burnout inventory, experience a higher level of burnout was found (Brake, Bloemendal and Hoogstraten, 2003; Greenglass and Burke, 1988). Yet in a study, there was result indicating that there was no significant difference regarding marriage burnout based on gender (Linzer et al., 2001). Factors of house-related work such as child care, housework, and meeting husband's needs in addition to having a job outside the house can be considered as effective regarding higher level of burnout in women.

According to the results obtained from the study, when $\mathrm{MB}$ of married individuals were examined according to the types of marriage, it was found that the ones who had arranged marriage was higher than that of the ones who married by acquaintance at a significant level. When the related literature was examined, it was found that couple harmony of the couples that got married by acquaintance was higher compared to the ones that had arranged marriage yet the couples that had arranged marriage got higher points regarding conflict in marriage (Şendil and Korkut, 2012). In their study, Xu and Whyte (1990) found that wives in love matches are more satisfied with their marital relationships than their counterparts in arranged marriages. In the study by Hortaçsu (2007) the individuals guided by their families and the ones who have marriage at their own will have been compared. It has been found that individuals married at their own will are more emotional, have less conflict with their families, and are more egalitarian. In consideration of the result obtained from the research and related literature, it has been observed that individuals who get married at their will have numerous advantages compared to the ones who have arranged marriage. Individuals who had an arranged married having more conflict (Şendil and Korkut, 2012; Hortaçsu, 
Pamuk, M., \& Durmuş, E. (2015).Investigation of burnout in marriage. International Journal of Human Sciences, 12(1), $162-$ 177. doi: $10.14687 /$ ijhs.v12i1.3002

2007), less sensibility (Hortaçsu, 2007), less satisfaction regarding marriage (Xu and Whyte, 1990), and less couple harmony (Şendil and Korkut, 2012) can be considered as the hints supporting the result obtained from the study that they have a higher level of marriage burnout.

According to the results obtained from the study, when MB of married individuals were examined according to state of being consanguineous, it was found that $\mathrm{MB}$ of the ones who were consanguineous was higher than that of the ones who are not consanguineous. According to the research carried out regarding this, it has been observed that the social support related partners get from their family is higher than that of the ones who performed arranged marriage (Özbey, 2012). In another study, the consanguineous marriage group had significantly lower marital adjustment and had more conflict with extended family than the nonconsanguineous marriage group (Fişıloğlu, 2001). Consanguineous marriage might be appealing for some reasons such as providing of social support to individuals and the approval of this situation by the surrounding environment. However, in consideration of the result of more conflict with the extended family obtained in the study of Fişloğlu (2001), social support obtained from consanguineous marriage might be replaced by social conflict. Since this situation may cause conflict problems both inter family and between families, it may also arouse negative psychological problems such as tension, anger, tiredness, fatigue, and burnout in married individuals.

According to the results obtained from the research, significant difference was found when $\mathrm{MB}$ was examined according to the variable of the number of children (No children, one child, 2-4 children, 5 and more children). According to this significant difference, it was found that $\mathrm{MB}$ of married individuals with 5 or more children were higher than that of those with no children. In consideration of the related literature, Glenn and McLanahan (1982) reported that married individuals with children have less marriage happiness. Based on the result of the study they conducted, Şendil and Korkut (2012) stated that the general quality of marriage of individuals reduces with the increase in the number of children. According to Allendorf and Ghimire (2013), having children may cause conflict among partners regarding the responsibilities of parenting. In their study, Akbolat and Işı (2008) found that the number of children affects the emotional and mental burnout of their parents. Regarding the higher burnout point of married individuals with children, partners having less time for each other, less communication, conflicts emerging due to parenting responsibilities can be considered as effective.

According to the results obtained from the research, significant difference was found when MB was examined according to the variable of the level of education (Illiterate, Primary School, Secondary School, High School, University). According to this significant difference, it was found that illiterate married individuals had a higher level of MB compared to that of all other individuals 
Pamuk, M., \& Durmuş, E. (2015).Investigation of burnout in marriage. International Journal of Human Sciences, 12(1), 162177. doi: $10.14687 /$ ijhs.v12i1.3002

at any other level of education. When the related literature was examined, Karahan and UyanıkBalat (2011) stated that educators who had a bachelor's degree experience a higher level of emotional burnout compared to those who are high school graduates. In their study, Şendil and Korkut (2012) found that individuals who were primary school graduates experience less couple harmony, couple satisfaction, couple togetherness, and emotional expression and more marriage conflict compared to those who had a bachelor's or higher degree. In consideration of the result obtained from the study and related literature, it has been observed that the lower educational level is, the more harmonious behavior declines, conflict increases and a higher degree of burnout emerges. According to Amato, Johnson, Booth and Rogers (2003), the advantages obtained by the increase in educational level may contribute to the increase in marriage quality.

In the equation model created in the study in order to determine the variables that predict $\mathrm{MB}$, it was found that each of the variables of SS, ICD, and DT significantly predict MB. These three variables explained $44 \%$ of MB. In consideration of the predicting variables in the order of priority, the order was determined as the variable of SS, ICD, and DT.

One of the variables considered in the study is SS. According to the findings, there was a negative medium level relationship between SS and MB ( $\mathrm{r}=-.57 ; \mathrm{p}<.01)$. Besides, the variable of SS was found to predict MB the most $(\beta=-.57 ; \mathrm{p}<.05)$. According to this result, as the support among the partners increases, partner burnout decreases. In this context, partner support can be considered as one of the important factors that prevent MB. In their study, Greenglass and Burke (1988) have found that social support is one of the significant predictors of burnout. According to Anis-ul-Haque and Sohail (1997), individuals experiencing high level of social support have better physical and mental health. A similar result has been reported by Keicolt-Glaser (2001). According to this, in good marriages, partners support each other in struggling with depression and physical ailment. Partner support does not only come to the fore regarding situations like ailment but also regarding daily routine. Amato et al. have found that (2003) increases in husbands' share of housework appeared to depress marital quality among husbands but to improve marital quality among wives. Aksüllü and Doğan (2004) found that a negative relationship between depression and social support in their study. According to this, factors of social support can said to have a positive impact on mental health.

Another variable considered in the study is DT. According to the findings, there was a negative medium level relationship between DT and MB ( $\mathrm{r}=-.45 ; \mathrm{p}<.01)$. Besides, DT was found to be a variable that predicts $\mathrm{MB}(\beta=-.12 ; \mathrm{p}<.05)$. According to this result, as the trust among partners increases, partner burnout decreases. Beckenbach et al. (2010) state that being trustworthy is to model a quality of commitment and security such that trusting can occur. Often in marriages one 
Pamuk, M., \& Durmuş, E. (2015).Investigation of burnout in marriage. International Journal of Human Sciences, 12(1), 162177. doi: $10.14687 /$ ijhs.v12i1.3002

person has dedicated him or herself to being the trustworthy person so that the other can exercise trust. Unless trusting and trustworthiness exist for both partners, there will be a limitation on the couple's growth. In their study on trust, Butler (1986) and Vinker, Finkenauer and Hawk (2011) suggest that the desire of one of the partners to control the other has a negative impact on the trust of the other partner. Negative impact of trust issues among partners may cause undesired situations such as stress, depression, and burnout in partners. Moreover, in cases where trust decreases or does not exist, partners may display less self-disclosure. This situation may cause negative outcomes such as less sharing among partners and less communication.

The last variable considered in the study is ICD. According to the findings, there was a positive low level relationship between $\mathrm{MB}$ and $\mathrm{ICD}(\mathrm{r}=.19 ; \mathrm{p}<.01)$. Besides, ICD was found to be a variable that predicts $\mathrm{MB}(\beta=.12 ; \mathrm{p}<.05)$. According to this result, as the cognitive distortions among partners increases, partner burnout increases. In consideration of the related literature, irrational beliefs have found to affect burnout in individuals (Ohue et al., 2011). Debord, Romans and Krieshok (1996) found that higher levels of general irrational beliefs correlated with lower levels of dyadic adjustment. Gündüz (2004) found that irrational beliefs as the most important predictor of burnout. Partners may encounter problems in their marriages due to irrational expectations among partners (Epstein and Eidelson, 1981). According to Güven and Sevim (2007), irrational expectations of partners may cause unhappiness. In their study, Tutarel-Kuslak (1997) found that partners experiencing disharmony performs negative attributions about their partner's behavior and these attributions cause marriage satisfaction to diminish even further. In consideration of the result obtained from the study and related literature, irrational beliefs and cognitive distortions have negative impact on married individuals. Irrational beliefs may cause unrealistic expectations of partners, decrease in marriage satisfaction, change in the perspectives of partners towards each other, and in connection with these it may cause undesired situations such as unhappiness, depression, stress, anger, and drawing away from partner. Such situations emerging in a marriage may cause boredom, fatigue, weariness, and burnout.

In line with the findings of the research, the following suggestions have been made:

1. In consideration of the fact that spousal support is the most important variable that predicts MB in this study, educational programs which will enable partners to support each other and emphasize partner support can be popularized; public service announcements can be prepared and broadcast on television.

2. Regarding trust that affects marriage burnout, education on pre-marital and marital trust building, development and issues along with the ways to struggle with these problems can be provided. 
Pamuk, M., \& Durmuş, E. (2015).Investigation of burnout in marriage. International Journal of Human Sciences, 12(1), 162177. doi: $10.14687 /$ ijhs.v12i1.3002

3. Regarding cognitive distortions that affect marriage burnout, education on how pre-marital and marital cognitive distortions /irrational beliefs may affect relationships and how to struggle with these can be provided.

4. In consideration of the fact that the number of studies on marriage burnout is limited in Turkey, researchers can work on marriage burnout with different groups and variables.

5. Researchers can conduct quantitative studies in order to investigate marriage burnout thoroughly.

\section{References}

Akbolat, M., \& Işık, O. (2008). Sağlık çalışanlarının tükenmişlik düzeyleri: Bir kamu hastanesi örneği. Hacettepe Sağhlk İdaresi Dergisi, 11, (2), 229-254.

Aksüllü, N., \& Doğan, S. (2004). Huzurevinde ve evde yaşayan yaşlılarda algilanan sosyal destek etkenleri ile depresyon arasındaki ilişki. Anadolu Psikiyatri Dergisi, 5(2), 76-84.

Allendorf, K., \& Ghimire, D. J. (2013). Determinants of marital quality in an arranged marriage society. Social ScienceRresearch, 42(1), 59-70.

Amato, P. R., Johnson, D. R., Booth, A., \& Rogers, S. J. (2003). Continuity and change in marital quality between 1980 and 2000. Journal of Marriage and Family, 65:1-22.

Anis-ul-Haque, M., \& Sohail, T. (1997). Stress, social support, and burnout in nurses. Pakistan Journal of Psychological Research, 12,3-4, 77-86.

Beckenbach, J., Patrick, S., \& Sells, J. (2010). Relationship conflict and restoration model: A preliminary exploration of concepts and therapeutic utility. Contemporary Family Therapy, 32, 290-301.

Brake, H. T., Bloemendal, E., \& Hoogstraten, J. (2003). Gender differences in burnout among Dutch dentists. Community Dentistry and Oral Epidemiology, 31(5), 321-327.

Butler Jr, J. K. (1986). Reciprocity of dyadic trust in close male-female relationships. The Journal of Social Psychology, 126(5), 579-591.

Couch, L., \& Jones, W. H. (1997). Measuring levels of trust. Journal of Research in Personality, 31,319336.

Çağ, P., \& Yıldırım, İ. (2013). Evlilik doyumunu yordayan ilişkisel ve kişisel değişkenler. Turkish Psychological Counseling \& Guidance Journal, 4(39), 13-23.

Çapri, B. (2013). Tükenmişlik ölçeği-kısa formu ile eş tükenmişlik ölçeği-kısa formu'nun türkçe uyarlaması ve psikoanalitik-varoluşçu bakış açısından mesleki ve eş tükenmişlik ilişkisi. Kuram ve Uygulamada Egitim Bilimleri [Educational Sciences: Theory \& Practice] - 13(3),13931418

Çapri, B., \& Gökçakan, Z. (2013). The variables predicting couple burnout. Ilkogretim Online, 12(2). 561-574.

Çetinkaya, E., Kemer, G., Bulgan, G., \& Tezer, E. (2008). İkili ilişkiler güven ölçeği’nin geçerlik ve güvenirlik çalışmalan. Türk Psikolojik Danısma ve Rebberlik Dergisi, 3(29), 65-77.

Debord, J., Romans, S. C, \& Krieshok, T. (1996). Predicting dyadic adjustment from general and relationship-specific beliefs. Journal of Psychology, 130, 263-280.

Epstein, N., \& Eidelson. R. J. (1981). Unrealistic beliefs of clinical couples: Their relationship to expectations, goals and satisfaction. American Journal of Family Therapv, 9, 1 3-22.

Etzion, D., \& Pines, A. (1986). Sex and culture in burnout and coping among human service professionals a social psychological perspective. Journal of Cross-Cultural Psychology, 17(2), 191-209. 
Pamuk, M., \& Durmuş, E. (2015).Investigation of burnout in marriage. International Journal of Human Sciences, 12(1), $162-$ 177. doi: $10.14687 /$ ijhs.v12i1.3002

Fişıloğlu, H. (2001). Consanguineous marriage and marital adjustment in Turkey. The Family Journal: Counseling and Therapy for Couples and Families,9, 215-222.

Freudenberger, H. J. (1974), Staff burnout, Journal of Social Issues, 30, 159 - 165.

Glass, D. C., McKnight, J. D., \&Valdimarsdottir, H. (1993). Depression, burnout, and perceptions of control in hospital nurses. Journal of Consulting and Clinical Psychology, 61(1), 147-155.

Glenn, N. D., \& McLanahan, S. (1982). Children and marital happiness: A further specification of the relationship. Journal of Marriage and the Family, $44,63-72$.

Gito, M., Ihara, H., \& Ogata, H. (2013). The relationship of resilience, hardiness, depression and burnout among Japanese psychiatric hospital nurses. Journal of Nursing Education \& Practice, 3(11), 12-18.

Greenglass, E. R., \& Burke, R. J. (1988). Work and family precursors of burnout in teachers: Sex differences. Sex Roles, 18(3-4), 215-229.

Gündüz, B. (2004). Öğretmenlerde tükenmişliğin akıllo olmayan inançlar ve mesleki bą̨ değişkenlere göre yordanması. Yayımlanmamış Doktora Tezi, Çukurova Üniversitesi, Sosyal Bilimler Enstitüsü, Adana.

Gündüz, B. (2005). İlköğretim öğretmenlerinde tükenmişlik. Mersin Üniversitesi Eğitim Fakültesi Dergisi, 1(1), 152-166.

Güven, N., \& Sevim, S. A. (2007). İliskilerle ilgili bilissel çarpıtmalar ve algılanan problem çözme becerilerinin evlilik doyumunu yordama gücü. Türk Psikolojik Danısma ve Rebberlik. Dergisi, 3(28), 49-61.

Hamamc1, Z., \& Büyüköztürk, S. (2003). İlişkilerle ilgili bilişsel çarpıtmalar ölçeği, ölçeğin geliştirilmesi ve psikometrik özelliklerinin incelenmesi. Çukurova Üniversitesi Ĕ̆gitim Fakültesi Dergisi. 2, (25),107-111.

Hooper, D., Coughlan, J., \&Mullen, M. (2008). Structural equation modelling: guidelines for determining model fit. The Electronic Journal of Business Research Methods. 6 (1), 53-60.

Hortaçsu, N. (2007). Family- versus couple-initiated marriages in Turkey: Similarities and differences over the family life cycle. Asian Journal of Social Psychology, 10, 103-116.

Hu, L. T., \& Bentler, P. M. (1999). Cutoff criteria for fit indexes in covariance structure analysis: Conventional criteria versus new alternatives. Structural Equation Modeling, 6, 1-55.

Karahan, S.., \& Uyanık-Balat, G. (2011). Özel eğitim okullarında çalışan eğitimcilerin öz yeterlik alg1larının ve tükenmişlik düzeylerinin incelenmesi. Pamukekale Üniversitesi Eğitim Fakültesi Dergisi, 29,1,1-14

Kiecolt-Glaser, J. K., \& Newton, T.L. (2001). Marriage and health: His and hers. Psychological Bulletin, 127(4), 472-503.

Kim, J. S., \& Lee, Y. S. (2013). Study on fatigue, stress and burnout of pregnant nurses. Korean Journal of Occupational Health Nursing, 22(3), 208-217.

Koolaee, A. K., Adibrad, N., \& Sedgh, P. B. (2009). The Comparison of relationship beliefs and couples burnout in women who apply for divorce and women who want to continue their marital life. Iranian Journal Of Psychiatry, 5(1), 35-39.

Kozak, A., Kersten, M., Schillmöller, Z., \& Nienhaus, A. (2013). Psychosocial work-related predictors and consequences of personal burnout among staff working with people with intellectual disabilities. Research in Developmental Disabilities, 34(1), 102-115.

Larzelere, R. E., \& Huston, T. L. (1980). The dyadic trust scale: Toward understanding interpersonal trust in close relationships. Journal of Marriage and the Family, 42, 595-604

Leaman, D. R. (1983). Needs assessment: A technique to reverse marital burnout. Journal of Psychology and Christianity, 2, 47-51.

Linzer, M., McMurray, J. E., Visser, M. R., Oort, F. J., Smets, E., \& De Haes, H. C. (2001). Sex differences in physician burnout in the United States and the Netherlands. Journal of the American Medical Women's Association,57(4), 191-193. 
Pamuk, M., \& Durmuş, E. (2015).Investigation of burnout in marriage. International Journal of Human Sciences, 12(1), 162177. doi: $10.14687 /$ ijhs.v12i1.3002

MacCallum, R.C., Browne, M.W., \& Sugawara, H., M. (1996). Power analysis and determination of sample size for covariance structure modeling, Psychological Methods, 1 (2), 130-49.

Maslach, C., \& S. E. Jackson (1981). The Measurement of experienced burnout. Journal of Occupational Behavior, 2, 99-113.

Ohue, T., Moriyama, M., \& Nakaya, T. (2011). Examination of a cognitive model of stress, burnout, and intention to resign for Japanese nurses. Japan Journal of Nursing Science, 8: 7686.

Özbey, S. (2012). Eşlerin algıladıkları sosyal desteğin ailenin bazı özellikleri ile ilişkisinin incelenmesi. Journal of Kirsehir Education Faculty, 13(1),167-181.

Pallant, J. (2001). SPSS survival manual. Buckingham: Open University Press.

Pines, A. M. (1996). Couple burnout: Causes and cures. New York: Routledge

Pines, A. M. (2005). Falling in love: Why we choose the lovers we choose.(Second Edition). New York: Routledge

Pines, A. M., Neal, M. B., Hammer, L. B., \& Icekson, T. (2011). Job burnout and couple burnout in dual earner couples in the sandwiched generation. Social Psychology Quarterly, 74, 361-386.

Ronen, S., \& Pines, A.M. (2008). Gender differences in engineers' burnout. Equal Opportunities International, 27, 677-91.

Sağlam-Arı, G., \& Çına-Bal, E. (2008). Tükenmişlik kavramı: Birey ve örgütler açısından önemi. Yönetim ve Ekonomi, 15(1). 131-148.

Schaufeli, W. B., Bakker, A. B., Van der Heijden, F. M., \& Prins, J. T. (2009). Workaholism, burnout and well-being among junior doctors: The mediating role of role conflict. $W$ ork \& Stress, 23(2), 155-172.

Schumacker, R. E., \& Lomax, R. G. (2004). A beginner's guide to structural equation modeling. Psychology Press.

Sümer, N. (2000). Yapısal eşitlik modelleri: Temel kavramlar ve örnek uygulamalar. Türk Psikoloji Yazıları, 3(6), 49-74.

Şendil, G., \& Korkut, Y. (2012). Evli çiftlerdeki çift uyumu ve evlilik çatışmasının demografik özellikler açısından incelenmesi. Psikoloji Calssmalar Dergisi, 28, 15-34.

Torun, A. (1995). Tükenmişlik, aile yapısı ve sosyal destek iliskilleri üzerine bir inceleme. Yayınlanmamış Doktora Tezi, Marmara Üniversitesi, Sosyal Bilimler Enstitüsü, İstanbul.

Tutarel-Kışlak, Ş. (1997). Evlilik uyumu ile nedensellik ve sorumluluk yüklemeleri arasındaki ilişkiler. Türk Psikoloji Dergisi, 12(40), 55-64.

Vinkers, C.D.W., Finkenauer, C., \& Hawk, S.T. (2011). Why do close partners snoop? Predictors of intrusive behavior in newlywed couples. Personal Relationships, 18, 110-124.

Xu, X., \& Whyte, MK. (1990). Love matches and arranged matches: A Chinese replication. Journal of Marriage and the Family, 52, 709-722.

Yalçın, S. (2013). Illköğretim okulu ögretmenlerinin mesleki tükenmişlik düzeyleri ile stres, psikolojik dayanıkhlı. ve akademik iyimserlik arasindaki ilişkei. Yayımlanmamış Yüksek Lisans Tezi. Gazi Üniversitesi Eğitim Bilimleri Enstitüsü, Ankara.

Yıldırım, İ. (2004). Eş destek ölçeğinin geliştirilmesi. Türk Psikolojïk Damışma ve Rebberlik Dergisi, 3(22), 19-26.

Yılmaz, V., \& Çelik, E. H. (2009). LISREL ile yapısal eşitlike modellemesi-I: Temel kavramlar, uygulamalar, programlama. Ankara: Pegem Akademi Yayincilik. 